\title{
Norwegian Tax News
}

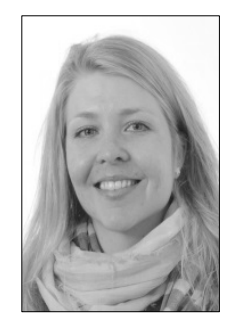

Senior Tax Adviser

Ingvild Brandal Gaasemyr

Tax Law Department

Norwegian Ministry of Finance

\section{Introduction}

In October 2013, Norway got a new government (the Solberggovernment) consisting of the Conservative party (Høyre) and the Progress Party (Fremskrittspartiet). In their joint declaration of assent (Sundvolden declaration) the Government stated that the tax level should be reduced and that tax revenues shall be used more efficiently. The Government also announced a goal to simplify regulations in general, including tax regulations.

The Government's objectives for its tax policies are to finance the welfare state, secure social mobility, achieve more efficient use of resources and provide better conditions for Norwegian businesses. The Government wants to strengthen private ownership, and stimulate people to work, save and invest - and to act more environmentally friendly.

In the 2014 Budget the Government abolished the inheritance tax and reduced the net wealth tax. The general tax rate was reduced from 28 pct. to 27 pct. and at the same time the tax rate of some special tax regimes increased with 1 pct. In May 2014 the Government presented its amendments to the 2014 Budget. The Government proposed only small adjustments to the tax system, cf. Prop. 94 LS (2013-2014). No significant structural changes concerning taxation of companies or individuals were proposed.

This article will present the most important changes to Norwegian tax legislation in force as from 1 July 2014. A list of tax treaties concluded in the same period is also provided. Finally, summaries of 3 
Supreme Court decisions in the tax area from first half of 2014 are presented.

\section{New legislation}

\subsection{Petroleum tax}

Petroleum tax is calculated on net income reduced by an uplift "friinntekt"). In 2013 the annual deduction rate was reduced from 7.5 pct. to 5.5 pct. over four years, for investments made after 5 May 2013. At the same time a transitional rule was introduced for investments according to a plan or an application for production and development etc. received by the Ministry of Oil and Energy before 5 May 2013. In the revision of the 2014 Budget the Government proposed some amendments to the transitional rule. The transitional rule is expanded to comprise the total project of development and transportation even if only one part of the project was received by the Ministry before 5 May, and some investments in other EEA states are also included. Finally, a time limit for the transitional rule is given for costs incurred after the income year 2021.

\subsection{The tonnage tax regime}

According to the new law regulating the rights of employees on board ships ("skipsarbeidsloven"), a shipping company is jointly and severally liable for employer obligations such as wages and holiday pay in cases where employees are formally employed by another company. This responsibility could potentially create income for the shipping company. Such income has previously been considered shippingrelated and therefore exempt from tax. However, the EFTA Surveillance Authority has expressed the opinion that this contradicted the EU guidelines on state aid to maritime transport. In the revision of the 2014 Budget, the Government therefore proposed to change the treatment of such income, making it liable for ordinary taxation. The amendment is applicable from the income year 2014.

\subsection{State aid: differentiated employer social security contributions}

According to the National Insurance Act ("folketrygdloven") all employers are obliged to pay employer social security contributions (employer SSC), calculated on the basis of gross salary paid to the employee. The general rate is 14.1 pct. Employers located in the least populated areas pay employer SSC at a reduced rate (from 10.6 pct. to 0 pct.). The reductions represent operating aid to the beneficiaries. Aid intensities vary with the geographical area in which the business is registered. This is the most extensive aid scheme in Norway. The EF- 
TA Surveillance Authority (the Authority) adopted new Guidelines on Regional State Aid for 2014-2020. On this background, the Norwegian authorities re-notified the employer SSC scheme. The scheme has expanded geographically to include 31 more municipalities, and the same time some sectors are excluded from the scheme. By decision No. 225/14/COL the Authority approved the scheme as compatible with the EEA Agreement. In June 2014 the Government presented a proposal to Parliament implementing the scheme, with effect as from 1 July 2014. The proposal was adopted by Parliament 20 June 2014.

\section{Tax treaties}

Information exchange agreements with Costa Rica, Uruguay and Niue entered into force in first half of 2014. The agreements are a result of the joint Nordic negotiations with tax havens, and are mainly in accordance with the OECD Model Agreement on Exchange of Information on Tax Matters. In February 2014 Norway signed a new double taxation treaty with Cyprus. The double taxation treaty is based on the OECD Model Tax Convention with some deviations.

\section{Case law}

\subsection{Rt. 2014 p. 227 "Petroleum tax"}

An oil company rented its offices from a wholly-owned subsidiary. The oil company was taxed at the special rate for petroleum activities, while the property subsidiary was subject only to ordinary taxation. As a result of a merger, the oil company no longer needed the offices, and a decision was made to sell the property. The sales process took time, and in the meantime the oil company continued to pay rent as required by the contract with the property subsidiary. The tax authorities argued that the decision to sell meant that the rental payments could no longer be considered costs related to petroleum activities and were therefore not deductible from the special tax base. However, the court found that the costs were deductible from the special tax base until the sale was actually completed.

After the sale had been agreed, the property subsidiary split into two companies, with one company owning nothing besides the office building in question. All the shares in this company were subsequently sold to the buyer. Gains from selling shares are not liable to tax according to the exemption method ("fritaksmetoden"). The tax authorities argued that the transaction was structured in this manner purely for tax purposes, and that the gain therefore should be taxed as if the 
property itself had been sold. However, the court did not find that the structure of the transaction was in breach of the intention of the relevant legislation. It was noted that the legislative body was fully aware of the potential for such transactions when the relevant legislation was passed.

\subsection{Rt. 2014 p. 196 "The exemption method and low tax-country"}

A Norwegian company established a wholly-owned subsidiary in Singapore. This subsidiary acted as the holding company for another eight operating companies registered in Singapore. The shares in the Singaporean holding company were later transferred to a whollyowned Norwegian subsidiary, causing a capital gain to be realised. The question before the court was whether this capital gain was subject to the exemption method and therefore tax free, or whether the capital gain was taxable as income from a low-tax country.

The general rule is that a company is considered registered in a low-tax country if that type of company has an effective tax rate lower than two thirds of what the same type of company has in Norway. The court found that the Singaporean holding company was a long-term investor and would primarily receive income in the form of dividends from its operating subsidiaries. As the tax rate for such income in Singapore is zero, the effective tax rate was clearly less than two thirds of the rate paid in general by Norwegian holding companies. However, as a result of the tax treaty between Norway and Singapore, a Norwegian holding company would also avoid paying any tax on dividends received from Singaporean operating subsidiaries. The court found that the tax treaty should not be taken into consideration, in order to ensure consistency with the rules governing the taxation of Norwegian-controlled foreign companies ("NOKUS"). The capital gain was therefore taxable as income from a low-tax country.

\subsection{Rt. 2014 p. 108 "Petroleum tax - exploration costs abroad"}

A Norwegian oil company had explored for oil in Angola and Denmark. The question before the court was how the exploration costs should be treated for tax purposes. Note that the law has since changed, so such costs are no longer tax deductible in any case.

The tax authorities argued that the costs related to exploration that was required by the license should be considered payment for the licence. Such payments are activated and amortised over the license period. Furthermore, costs related to exploration beyond what was required could only be deducted immediately in those cases where the well was dry.

However, the court stated that as long as the exploration activity that was required by the licenses did not exceed what would be con- 
sidered normal exploration activity, the costs should not be considered payment for the license. The court further stated that any costs related to exploration activity prior to a commercial discovery should not be considered investments, but as running costs. Such expenditure could therefore be deducted immediately from taxable income. 